九州大学学術情報リポジトリ

Kyushu University Institutional Repository

\title{
Farm Management and Farming Systems Development in Vietnam
}

Duong, Le Thanh

Laboratory of Farm Management, Faculty of Agriculture, Kyushu University

Cho, Kenji

Laboratory of Farm Management, Faculty of Agriculture, Kyushu University

https://doi.org/10.5109/24061

出版情報 : 九州大学大学院農学研究院紀要. 39 (1/2), pp.1-8, 1994-12. Kyushu University バージョン：

権利関係: 


\title{
Farm Management and Farming Systems Development in Vietnam
}

\section{Le Thanh Duong* and Kenji Cho}

\author{
Laboratory of Farm Management, Faculty of Agriculture, \\ Kyushu University, Fukuoka 812, Japan \\ (Received April 10, 1994)
}

\begin{abstract}
By some significant institutional incentives and technological improvements, agriculture in Vietnam has made a remarkable progress in its intensity and productivity for the last decade. It resulted in a significant change in agricultural production and rural economy. Nowadays, although Vietnam becomes the third largest rice exporting-country in the world, the farmer's living standards have not much been improved due to the present unfavorable price condition of rice and relatively high price of input materials. Environmental problems also become to be a new issue particularly in the advanced areas in the Mekong delta region where a highly intensive cultivation of rice in continuous triple cropping system has been practiced.

Recent researches showed that diversified farming seems to be better for small-scale farmers, and through integrated farming systems development approaches rice-based agro -ecosystems can be turned to more profitable farming for a sustainable agriculture and rural development. Introduction of appropriate farming practices can make better uses of lands, water and other resources at lower costs and maintain the sustainability of the environment. Integration of non-rice crops, livestock, aquaculture and other activities into rice systems can become a new approach to farmers.

The present paper is aimed to review the outlines of the recent activities in research, extension and training for sustainable agriculture and rural development in Vietnam.
\end{abstract}

\section{INTRODUCTION}

After the war, Vietnam's agricultural production was mainly planned on the basis of self-sufficiency, and the concept of individual farmers was not recognized under the orthodox socialist approach. Rice production therefore stagnated while the population kept on growing at a considerable rate of more than 2.3 percent per year (Xuan, 1991). In order to overcome the problem, the government reversed its strategies with more improvements on land tenure, farm management and some other support services since 1986.

Due to the open door policy in agriculture, remarkable progress has been achieved by recognizing individual farm household economy as a basis of agricultural production development. Farmers have been encouraged with some governmental incentives to invest and manage individually their land holdings. No longer can they work on cooperative farms but for their profit at their own risk. Since 1989 Vietnam has become the third largest rice-exporting nation in the world with 1.5-1.8 million tones

\footnotetext{
* Present address : Mekong Delta Farming Systems Research and Development Center, University
} of Cantho, Vietnam. 
of milled rice every year. However, the living standards of rice farmers have not much been improved because of high inputs in production and low output prices. Rice production has especially been difficult in northern and central parts of Vietnam. It was mainly due to unfavorable weather conditions (low temperature, frequent drought and typhoons, and submergence), degraded soils, insect pests and diseases, and smaller size of farms. Monoculture rice farmers remained poor but farmers who adopted diversified farming with crops other than rice could earn better incomes. Efforts to increase rice production can affect the environmental sustainability with more destroyed forests, increasing chemicals application, and more occurrence of harmful insect pests. In the South the conditions are more favorable, especially in the Mekong delta. However, eventhough high rice yields of $10 \sim 12 \mathrm{t} / \mathrm{ha} / \mathrm{year}$ has been recorded in some parts of the Mekong delta, it was the result of the application of large quantity of chemicals and other inputs. It is obvious that, due to dependency on a single crop in both irrigated and rainfed areas, the farmers' income and their living power remained low, even with better output prices.

Recent findings from various researchers, surveys, and experiments indicated that through integrated farming systems development approaches these rice-based agro -ecosystems can be turned to more profitable farming (Xuan, 1991), and rice farmers shifting to a more diversified agriculture can earn better incomes. More recently scientists and agricultural policy makers in Vietnam have been accepting the idea of agricultural diversification and are now paying more attention to farming systems approaches for sustainable agriculture and rural development (SARD). These issues are in top priority for the 1990's and beyond. The present article is aimed to review the outlines of recent activities in research, extension and training for SARD in Vietnam.

\section{ACTIVITIES}

\section{Research}

Some initial research activities were done long time ago to describe socioeconomic characteristics of various agro-ecosystems in the Mekong delta where rice farmers contributed a large quantity of paddy to total rice production of the country. However, with a planned agricultural production set up after 1975 farm management and production profitability were therefore slighted. It took ten years with unforgettable experiences before the government decided to change its policy towards a market economy.

Introduction of appropriate farming practices can make better uses of lands, water, and socioeconomic resources at lower inputs and in the meantime maintains the sustainability of the environment. Integration of non-rice crops, farm animals, aquaculture, and other off-farm and non-farm activities into rice systems can become a new approach for farmers. Much attention has to be paid to agroforestry in order to exploit efficiently and effectively various kinds of resources. Socioeconomic aspects of farm households also need to be understood as a basis for identifying strategies to improve farm incomes.

The Mekong Delta Farming Systems Research and Development Center of the 
University of Cantho was founded in 1988 with its main activities mostly concentrated on rice-based farming systems. For several years the Center has served as a nucleus of the Vietnam Farming Systems Research and Extension Network (VNFSREN) which was established in 1990, consisting of ten research groups from nine member institutions, as below listed.

FSR group, Agricultural University No. 1, Hanoi

FSR group, Agricultural University No. 2, Hue Mountainous and Hilly

Agroforestry R \& D Center, Agricultural University No. 3, Bacthai

FSR group, University of Western High Plateaux, Daklak

FSR group, University of Agriculture and Forestry (UAF), Ho Chi Minh City

FSR group, Cuulong In-service Training College, Vinhlong

Mekong Delta FSR Development Centre, University of Cantho, Cantho

Rice-Fish group, Cuulong Rice Research Institute (CLRRI), Cantho

Department of FSR, Southern Institute of Agricultural Science (SIAS),

Ho Chi Minh City

A multidisciplinary team has been formed in every research group to work with interdisciplinary problem, whose composition is mostly an agronomist, an agricultural economist, a soil scientist, an integrated pest management expert, an aquaculturist, and an animal husbandry scientist.

The general objectives of the VNFSREN could be described first to develop human resource capabilities in FSRE approaches, and second to improve and further develop appropriate agricultural systems which are both economically and environmentally sustainable and simultaneously will improve farm household incomes, nutrition, and welfare.

Five specific objectives included in FSRE approaches are as follows :

(1) To develop a -national research and extension capability in FSRE approaches, including university and college researchers, district technicians, local administrators, farmer's leaders, and policy makers.

(2) To develop income enhancing and/or diversified sustainable agricultural production systems for various agro-ecosystems in Vietnam.

(3) To develop integrated agriculture-aquaculture farming systems in selected production areas.

(4) To develop improved production systems for pigs and other large ruminants in selected sites in the six regions of Vietnam based on more effective uses of crop residues and forages.

(5) To monitor and evaluate socioeconomic changes associated with the above improvements.

Network activities are supported by the International Development Research Centre (IDRC), Canada, for the 1992-1995 phase. Baseline data were obtained through benchmark surveys on 28 main research sites and 4 supplementary ones representing all the agro-ecosystems throughout Vietnam. The data from these surveys were processed and analyzed with active leadership of farm management specialists and agricultural economists of each research team or group.

The farm management systems in Vietnam have changed from strict collectivization to free enterprise by farm households. This reverse has brought about a restructure of the farm operation in every household, and farmers had to decide what are their 
best in term of economic profitability. However, because of different production conditions including farm size in different agro-ecosystems the farmers' behavior and preferences also varied much.

Phat (1992) conducted integrated natural and socioeconomic resources research in 30 representative districts of the country. From their report the followings could be pointed out as the features of the majority of farm households in Vietnam.

(1) Small-scale production with land holding of 0.3-1.0 ha is most popular in small farm household size (5-6 families with 2-3 persons in working age), poor farm implements, and inappropriate technologies.

(2) Agricultural production is mostly subsistent rice production whereas animal husbandry, off-farm, and non-farm activities are less considered. Only 30-40 percent of farm households could produce marketable surplus. Some farmers earning high incomes usually focus on highly valuable agricultural products.

(3) Mechanization in agricultural production is in low requirement because of the abundant labor resource. Enlarging production is therefore limited due to low capital deposition. They need some kinds of easy-term credit for applying advanced farming practices.

(4) Income contribution to total farm household revenue is derived from crops (60 -80 percent), domestic animals ( $10-30$ percent), and off-farm jobs (5-10 percent). The poorest farmers are monocropping food grain/tuber producers while the better ones apply various advanced farming systems.

(5) The marketing policy must be considered because farmers are now facing to unstable and unfavorable output prices.

Xuan (1992) showed in his study on household economy in Central Vietnam in 1988 that gross return per household is still low ( 2.87 million VND/year) in which 47 percent is from crops, 24 percent from animal husbandry, 4 percent from forestry, and 24 percent from other sources. Land allocated to farm household is so limited while the household size is medium (5-6 persons) with 2-3 persons in working age. Besides limited land resource, farm household economy in Central Vietnam is low due to bad production management and lack of capital. For a better production development it is necessary to enlarge arable lands by exploiting more abandoned lands, to give considerable loans with low interest rates to farmers, to apply more farm implements, and to train farmers on adopting new farming technologies.

Ngan and Liem (1992) studied the affects of some socioeconomic factors on farm household incomes in different agro-ecosystems in Thua Thien province (Central Vietnam) through field surveys on 531 households in 1990. The results showed (1) household net return is still very low in rice production areas due to limited land resource and lack of capital input ; (2) farm income is high in households with much family labor, high material inputs and implements ; and (3) farm income is higher and more stable in households with integrated systems of crops, animal husbandry, and other offffarm and non-farm activities.

Numerous research papers presented during the previous workshops and meetings of the VNFSREN emphasized on farm management and economic aspects of current and proposed improved production systems. Duong (1992) recorded that the two -modern rice crop systems (21LR) can give higher net income than the deepwater rice monoculture (DWR) in the Mekong delta, yet its benefit-cost ratio is lower than DWR 
( 0.82 vs. 2.44) because of high cost production in $21 \mathrm{LR}$ that is thought to be due to high material and labor inputs. Farmers can obtain more incomes by growing upland crops (VC) after DWR, of which eggplant, cowpea, and squash give the highest benefit -cost ratio $(4.25,1.90$ and 1.60$)$. In rice-prawn systems in fresh water areas in the Mekong delta Dung et al. (1992) also indicated that between the two most popular prawn systems the 21LR has less amount of gross return than the wet season ILR followed by the traditional rice crop (TPR)(5.6 million VND vs. TPR). The net income and BCR of the former are also higher than the latter (5.8 million VND/ha vs. 2.9 million $\mathrm{VND} / \mathrm{ha}$; and BCR 3.1 vs. 2.1).

Intercropping pulses with cassava in southeastern and central coastal Vietnam, Hoang Kim (1992) presented two highly profitable cropping systems. The first is one row of cassava/winged-bean intercropped with two rows of mungbean using new varieties of cassava (HL24, Rayon60), mungbean (HL89-E3), and winged-bean (Binh Minh, HL86-3, HL86-7) practiced with appropriate cultivation techniques. The system can give an increase in gross margin of 25 percent higher than that in monoculture cassava. The second is one row of cassava/winged-bean intercropped with two rows of peanut using new varieties of cassava, winged-bean, and peanut (HL25, HL28, Ly, Giay). This type of cropping system yields a return above variable costs (RAVC) of 35-85 percent higher than that in monoculture cassava.

Quoc (1992) showed that the two-rice crop systems on degraded gray soils in the Mekong delta often give low economic returns to farmers due to reduced soil nutrition. In Duc Hue, Long An, mungbean, peanut, and cowpea have been introduced in areas where 1-3 rice crops/year are now being practiced. On rainfed degraded soils on -farm experiments showed that the 2 rice-cowpea systems can give higher economic return than the two rice crops alone. Also on irrigated degraded gray soils the 2 rice -peanut (or mungbean) systems have higher economic return than the 3 -rice monoculture.

\section{Extension}

Recognizing farm household economy as basis of agricultural production development has really encouraged farmers to use all of their farm resources to obtain higher production and incomes. It is indispensable to extrapolate advanced technologies to farmers, hence agricultural extension must play an important role in farming systems development for SARD. However, these activities used to be slighted in a planned economy because most of the government officers at all levels are lacking of awareness and appreciation of agricultural extension in SARD; and in previous times the technicians went to farmers with technical mandates from the government (Tiem, 1993).

Nowadays the situation is being changed. Agricultural extension is recognized as an important component in farming systems development. Officially extension work has been started since the Vietnam Premier signed the decree No. 13-CP on 2nd March, 1993 on the formulation of a national agricultural extension organization. However, in the South agricultural extension activities have been existing for a long time, even before 1975. Some provincial Departments of Agriculture recognized early the importance of agricultural extension in agricultural production development, so they worked by their own in collaboration with some agricultural universities and 
research institutes. Those activities can help several provinces obtain better results in agricultural development, several provinces in the Mekong delta are now obtaining an annual production of more than one million tones of paddy, and the total rice production of the region therefore increases up to more than ten million tones.

As mentioned before rice monoculture farmers could not earn high incomes due to high production costs, even in the Mekong delta. In order to obtain higher incomes to improve their living standards they must change to a diversified agriculture for better uses of physical, biological, and socioeconomic resources. With the establishment of the VNFSREN in 1990 much attention has been paid to FSD approaches. Scientists, including farm management specialists involving in the network, have continued doing research and disseminating the results to farmers in many regions throughout Vietnam. Advanced technologies are now being extrapolated directly to farmers or groups of farmers in cooperation with many provincial Extension Departments. The mass media, group media, and interpersonal contact have been used to train extension workers, local administrators, farmer's leaders, and individual farmers. Identification of advancing farmers must be done prior to organize training courses, and the farmer-to-farmer approach can be practiced, using outstanding farmers to train other farmers.

\section{Training}

Farming systems research and development approaches have been introduced into Vietnam only for a few years, and many Vietnamese scientists therefore did not fully understand the basic concepts. This is reflected by research and publications classified as "farming systems" work, which are often single component researches put together without a clear systems approach, or far away from the farmer's real needs (Xuan, 1991).

The VNFSREN was formed to fulfill the needs of Vietnamese agricultural scientists through training in farming systems research extension approaches. The first training course on FSRE which was held from 8th February to 3rd April, 1993 at the University of Cantho with 28 participants from 10 research groups of all the nine members institutions of the VNFSREN was really an attempt to provide to scientists and researchers of the network basic principles and practices on FSRE. Special gratitude was due to IRRI Training Center's training specialist, Mr. Armando S. Erguiza, who actively participated in planning, organizing, and also giving lectures in the training. Recommendations were also given by Dr. Clive Lightfoot of International Center for Living Aquatic Resources Management (ICLARM) on agroecosysterns analysis based on resource systems using the RESTORE software developed by ICLARM.

Although numerous training courses on many agricultural disciplines have been organized for researchers, technicians, and even farmers they are monodisciplinary and only respond to specific and narrow problems. Never had a training on FSD been held before the mentioned first training was organized. Farm management specialist played a key role in the course, and socioeconomic aspects are important components of the course contents because farmers' objectives and preferences are focusing on economic profitability and local infrastructure compatibility.

Some researchers and extension workers from the University of Cantho and other 
member institutions were recently sent abroad for short and long-term studies on farm management, FSRE and Training and Technology Transfer methodology. Some economists from the University of Cantho, the University of Agriculture and Forestry, and the Agricultural University No. 1 have already received some training in survey methods started some years ago by IRRI. They will be key resource persons in the future incountry training courses. The trainer-trainee approach has been followed in Vietnam to allow rapid generation of trained resource persons in courses for district technicians, local administrators, and advanced farmers.

\section{CONSTRAINTS AND RECOMMENDATION}

Most of agricultural economists and farm management specialists have been trained in Marxian schools for a planned economy, therefore partial and whole farm budgeting procedures, benefit-cost analysis, and many other aspects in microeconomic analysis are new to them. In previous times scientists did not care the economic profitability of farming activities because all were subsidized by the government. On the move towards a market economy our top priority is to update the concepts, knowledge, and skills in microeconomics for those who are working on economics and farm management.

Lack of information has been one of the most important constraints for economic development because updating knowledge means a requirement of reference books, research papers, newsletters, journals, microcomputer and other communication facilities. However no budget has been allocated for those permanent subscriptions. Information and other scientific publications have only been gotten through collaborative research projects, and were not widespread. It is advisable to introduce new publications and books on economics and farm management for reference in universities and colleges.

Poor human resource development can slow down the national economic development because very few university staff have been sent abroad for economics and farm management training. Many others need to be trained so that they will perform very well in research and management. For FSD it is necessary to train many people : scientists, faculty members, researchers, technicians, extension workers, and also advanced farmers on FSRE approaches.

First of all, human resource development must be considered. A number of researchers must be sent abroad for long-term and short-term studies in FSD and farm management with fundings from international organizations : FAO, UNDP, IDRC, AIDAB, WINROCK, etc. Bilateral and multilateral development projects should be prepared to submit to donor agencies for funding. These people will be resource persons for later incountry trainings.

The problem of information deficiency must be solved by permanent subscription of research journals and papers, buying reference books, computer and CD-ROM. Also the number of people sent abroad for attending trainings, workshops, meetings, and symposia must be increased, using funds from collaborative development projects. An assignment must be set up with the National Information and Documentation Center for Science and Technology of the Ministry of Science, Technology, and 
Environment, Vietnam, to improve information exploitation in farm management.

Agricultural extension has always played a key role in SARD, yet no attention was paid before to these activities. The FSRE approaches which were introduced into development projects in Vietnam few years ago can help the central and local government officers improve their awareness and appreciation of FSD in SARD. Training of extension workers for FSD is really indispensable.

\section{REFERENCES}

Phat, C. D. 1992 Study on farm household economy. (in Vietnamese)

Kim, H. 1992 Intercropping pulses with cassava in Southeastern and coastal areas in central Vietnem. (in Vietnamese)

Quoc, H. T. 1992 The use of leguminous plants in rice cropping systems on degraded grey soils in Due Hue district, Long An. (in Vietnamese)

Dung, L. C., L. T. Duong and V. T. Xuan 1992 Implementation of rice-shrimp farming systems in freshwater areas in the Mekong delta of Vietnam.

Duong, L. T. 1992 Deepwater rice farming systems in the Mekong delta of Vietnam.

Tiem, L. T. 1993 Agricultural extension activities in Bac Thai province, Vietnam. (in Vietnamese)

Xuan, M. V. 1992 Household economy in agricultural systems and its perspectives. (in Vietnamese)

Ngan, P. D. and Hoang Liem 1992 Affects of some socioeconomic factors on farm household incomes in agro-ecosystems in Thua Thien-Hue. (in Vietnamese)

Xuan, V. T. 1991 Project proposal submitted to IDRC on Farming Systems Research \& Extension Network in Vietnamese. 